\title{
Dialects in Animals: Evidence, Development and Potential Functions
}

\author{
Laurence Henry $^{1 *}$, Stéphanie Barbu ${ }^{1}$, Alban Lemasson ${ }^{1}$, and Martine Hausberger ${ }^{1}$ \\ ${ }^{1}$ Université de Rennes \\ *Corresponding author (Email: 1henry@univ-rennes1.fr)
}

Citation - Henry, L., Barbu, S., Lemasson, A., \& Hausberger, M. (2015). Dialects in animals: Evidence, development and potential functions. Animal Behavior and Cognition, 2(2), 132-155. doi: 10.12966/abc.05.03.2015

\begin{abstract}
Dialects are one of the parallels that have long been established between human language and animal communication. We discuss the potential functional parallels between human and animal dialects, arguing that in both cases different mechanisms and functions may be at stake where large geographical versus very localized (e.g. social) variations are concerned. Birdsong studies in particular, but also recent studies of mammal vocalizations, show that the use of the term "dialect" to refer to within-species vocal variations in animal species is more than a metaphor and that animal dialects offer a possibility to explore the causes and functions of linguistic variation and change, one of the challenges in exploring the origin of diversity of language families. We present here an original view, as our approach was not "primate-centered," and take into consideration "homoplasy" (analogy) as a potential mechanism to explain that different taxa have evolved the same functional response to social constraints.
\end{abstract}

Keywords - Dialects, Vocal communication, Birds, Mammals, Evolution of communication

Research into the roots of human language in animal vocal communication is a matter of considerable controversy, given the presumed uniqueness of human language. This leads to active discussions about the importance of establishing parallels between human language and animal communication (Hausberger, Henry, Testé, \& Barbu, 2008; Hauser, Chomsky, \& Fitch, 2002; Lemasson, 2011; Masataka, 2003; Zuberbühler, Ouattara, Bitty, Lemasson, \& Noë, 2009). Dialects are one of these parallels. Thus, linguists are interested in and debate about the adaptive value of dialect differentiation and linguistic diversity in humans (Chambers, 1985; Labov, 1972) by studying dialectal forms and functions (Chambers, 2003; Fasold, 1985) as well as their level of geographical variation (Chambers, 2003; Moulton, 1985). Ornithologists have similar questions about birdsong, and find here a quasiexperimental possibility of understanding such questions as many different species, that differ in population structuring, social organization, spatial distribution, provide a whole field of comparative investigation (Payne, 1981; Thorpe, 1961). Because convergence (or homoplasy) is a common phenomenon in evolution leading to similar functional adaptations in response to similar ecological and social conditions in phylogenetically distant groups (Deleporte, 2002; Martins, 1996), comparing distant groups with some similar social evolutionary requirements such as birds and humans does make sense and may help understand evolutionary trajectories. This is the core of the researches on the evolution of vocal communication and hence language. It is also the basis for comparing differentiation and changes in both humans and animals. Here, we will argue that the use of the term "dialect" to refer to within-species vocal variation in animal species is more than a metaphor and that animal dialects offer a possibility to explore the causes and the functions of linguistic variation and change, which is one of the challenges in exploring the origin of diversity of language families (Labov, 2002).

In the present paper, we will focus on the potential convergences between human language and animal vocalizations but will leave aside issues such as semantic or referential communication which are 
controversial beyond even the question of dialects. Some aspects of language rely upon human specific skills (i.e., use of semantic symbols, register change or even code switching). We present here a critical review on dialects in animals (sound structure, phonological syntax defined as a meaningless arrangement of elements by Marler (1977), with a special focus on European starlings for which extended studies have been performed, by examining potential parallels with human language. After presenting human dialects' form and function, we will recounting the history of studies of geographical variations in animals and explain why birds have come out as a privileged model for such comparisons with human species. The different hypotheses on the origin and functions of dialects will be described.

\section{Dialects in Humans: A Reminder}

In humans, within-language variation at any linguistic level (i.e., from phonology to syntax) is not haphazard, but is instead structured along a number of superimposed factors, such as the speakers' geographical location, their socio-demographic characteristics (e.g., socio-economic status, gender, age, ethnicity), their integration and location within social networks, and/or the situational context of speech (e.g., the degree of formality, the identity of the addressee...) (Chambers, 2003 for reviews; Labov, 1972, 2001).

According to Wolfram's (1998) definition, human dialect refers to "any regional, social or ethnic variety of a language" that includes variations at several levels such as pronunciation, grammatical, semantic and language use differences. The geographical distribution of dialectal variants in human languages includes the existence of sharp boundaries or isoglosses at the outer limits of the core area of a given dialect as well as important transition areas in which a range of interdialectal forms are found (Britain, 2002; Chambers \& Trudgill, 1998). Examples of individuals who use the two neighboring variants are common in humans. Superimposed levels of variation may occur and it is said that "each word has its story" (Petyt, 1980). Thus, in a study on the pronunciation of given words in three towns in East Anglia, Chambers and Trudgill (1998) found that the dialectal area for the pronunciation of the word "road" separated Colchester from the northern towns of Ipswich and Lowestoft, while the pronunciation of the word "rowed" separated Lowestoft from the two other towns. The dialectal boundaries were therefore not the same in both cases. Therefore, it looks as if each word had evolved along time at its own dispersing time and correlated to a human group that differed from that of another group. People of some sites could converge on the pronunciation of some words and diverge on other words, each word potentially bearing different social meanings and hence defining different communities (for some part shared with the other word).

There is increasing evidence showing that some aspects of the structured variation found in adult speech are evident from the very start of language acquisition (Nardy, Chevrot, \& Barbu, 2013), and that children begin to adjust their use of nonstandard or local variants to the situational context of speech at the same time (Patterson, 1992; Roberts, 2002; Smith, Durham, \& Fortune, 2007). While children encounter variation in the language spoken around them, they do reproduce these dialectal features at an early age (Barbu, Nardy, Chevrot, \& Juhel, 2013; Chevrot, Nardy, \& Barbu, 2011). Although variation in both children's input and output has been notably neglected in acquisition studies, being mostly considered as "noise," a growing body of sociolinguistic studies indicates that variation should not be considered as merely a by-product of the learning process, but as an integral part of acquisition itself and as a form of social practice with social meaning (Eckert, 2000; Foulkes \& Docherty, 2006; Foulkes, Docherty, \& Watt, 2005; Roberts, 2002; Smith et al., 2007). Therefore, empirical evidence from human dialects is consistent with the effects of socialization and social learning. These studies converge to recognize that variation is socially meaningful and that dialects may primarily serve a social function (Chambers, 2003; Labov, 2001; Snowdon \& Hausberger, 1997). Speakers have more than one way to say the same thing, dialectal variants being equivalent in their referential meaning (Labov, 1972).

Beyond what is said, how speakers say something can carry information about their social identity, their relationship to the addressee or the situational context of speech. Differences in dialects thus carry social meaning (Campbell-Kibler, 2009) and serve mainly the social identity function (Fasold, 
1985). Local dialects have an important function by promoting social integration into local networks (Eckert, 2000). By considering language, as well as animal communication, primarily as a social action, some biologists and linguists have emphasized their dimensions of communicative purposes that are identity and relational goals (i.e., personal or social identification and personal or group relationships) (Coupland, 2001; Snowdon \& Hausberger, 1997)

As we will discuss it further in animals' dialect section, genetic adaptation has been also proposed to explain human dialect maintenance. However, despite some evidence that large scale dialects may interfere in partner choice in human populations, especially when they are considered as a factor of cultural identification (e.g., Lee \& Gourley, 1988 on Chinese dialects; Nagoshi, Johnson, \& Danko, 1990; Stanfort, 2010), human dialects as genetic adaptation mechanisms do not seem a plausible assumption either as they do not seem in overall to be a primary criterion of choice, especially where local dialects are concerned (Chambers, 1985, 2003; Moulton, 1985).

\section{Geographical Variations and dialects in Animals: History, Definitions and Spatial Distribution}

\section{The Early Birdsong Model}

From the most ancient times, naturalists and ornithologists have mentioned that the songs of a variety of birds did not "sound the same" in distant locations (Pliny the Elder, 1848). Greenland Eskimos used local dialects of snow buntings to identify particular headlands (Nethersole-Thompson, 1966). Darwin (1871) was probably one of the first to refer to slight differences in the songs of a given species in different locations as "provincial dialects", although there does not seem to be a historical record of when this term became established for animal communication. Geographical variations of songs were clearly known but remained subjective assessments and therefore largely unexplored until methodological tools were developed in the early 1950s that enabled graphic representations of sounds and therefore precise measurements (Thorpe, 1954).

One of the classical studies was the description of variations on a large geographical scale of the "rain call" of chaffinches (Fringilla coelebs), showing that the structure of this call varied between different European populations (Poulsen, 1951; Thorpe, 1958), referred to as "geographical variations." This was followed by the description of local variations, labeled as "dialects", in the songs of whitecrowned sparrows (Zonotrichia leucophrys) by Marler and Tamura $(1962,1964)$.

Terminology reflects the scale of variations: it is common to discriminate "geographical or even macrogeographical variations" occurring over hundreds of kilometers from "dialects or microgeographical variations" where variations may occur over just a few kilometers or even a few hundred meters (e.g., Jenkins, 1978; Mundinger, 1982).

The first case can be illustrated by the great tit (Parus major) whose songs include 2 or 3 "syllables" according to the area: these two forms are widely distributed over huge areas of Northern Europe (Bergman, 1980; Lehtonen, 1983). European populations clearly also differ from Indian and Japanese populations (Thielcke, 1969). The other extreme is found in Indian Hill Mynahs Gracula religiosa (Bertram, 1970), caciques Cacicus cela (Feekes, 1982) or indigo buntings Passerina cyanea (Payne, 1983) where the variants (local form of the song) characterize a colony or a group of neighbors. The saddleback (Philesturnus carunculatus) lives in long term pairs which occupy territories with the same neighbors over years. Each male has a repertoire of 1 to 4 song types and shares his song types with 2 to 8 near neighbors (Figure 1). Young birds leave the natal dialectal group and join another, where they learn the local dialect from their neighbors (Jenkins, 1978). Intermediate cases are for example found in the songs of white crowned sparrows where variations occur along the west coast in North America over just a few kilometers (Figure 2).

Many authors consider that dialects result from social learning (Jenkins, 1978; Leader, Geffen, Mokady, Yom-Tov, 2008; Payne \& Payne, 1997), while there is some evidence that large-scale variations may rather reflect habitat differences and result from acoustic constraints (e.g., Bowman, 1979). Indeed, Benedict and Bowie (2009) demonstrated that the song of the red-faced cisticola (Cisticola erythrops) 
varies according locations across Africa and that differences corresponded to gradual geographical variations over very large distances. In such cases however, there are no sharp boundaries delimiting dialect areas.

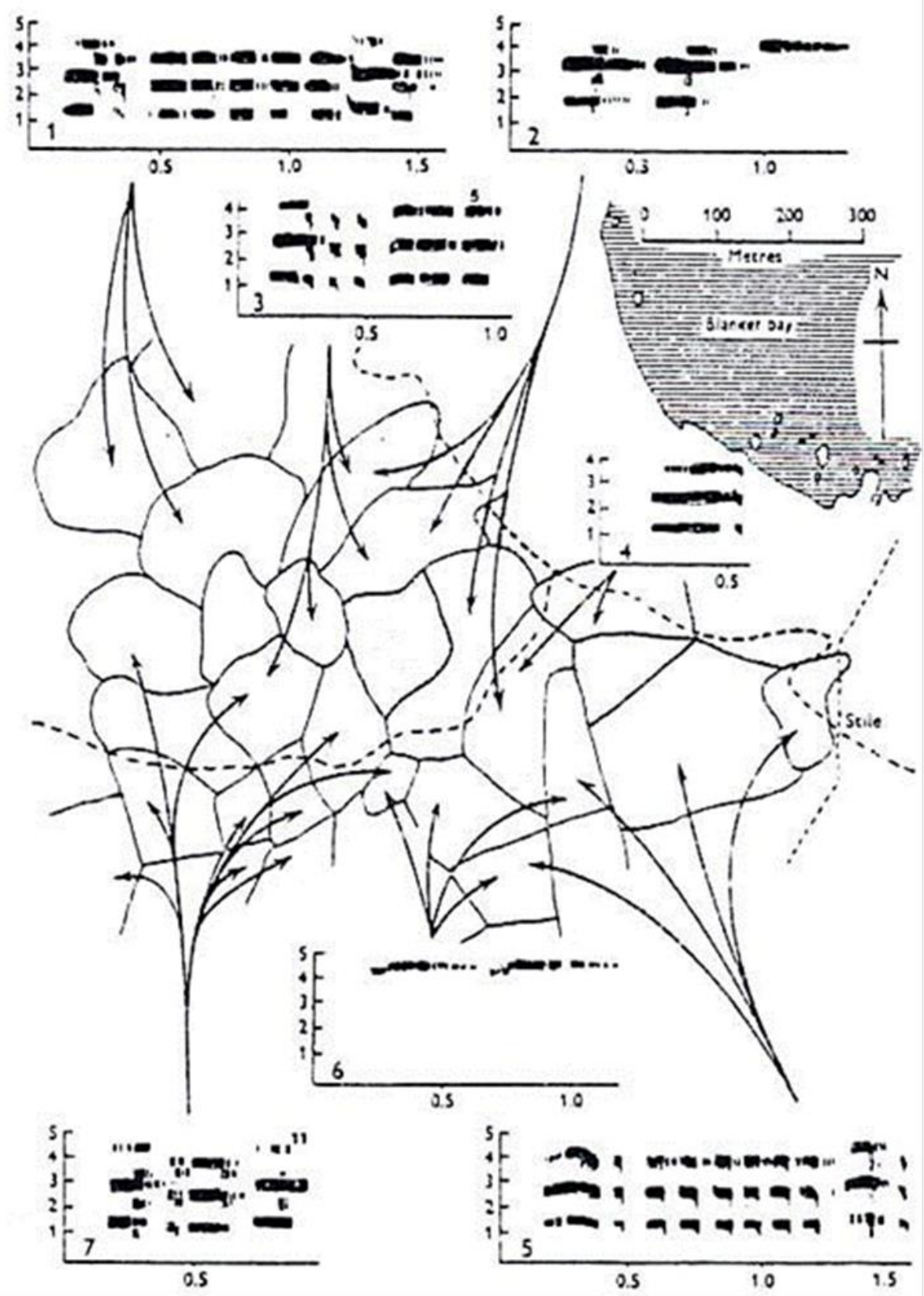

Figure 1. Microgeographical variations in Calladeidae. Territories and sonograms produced by different individuals are represented (Jenkins, 1978). 


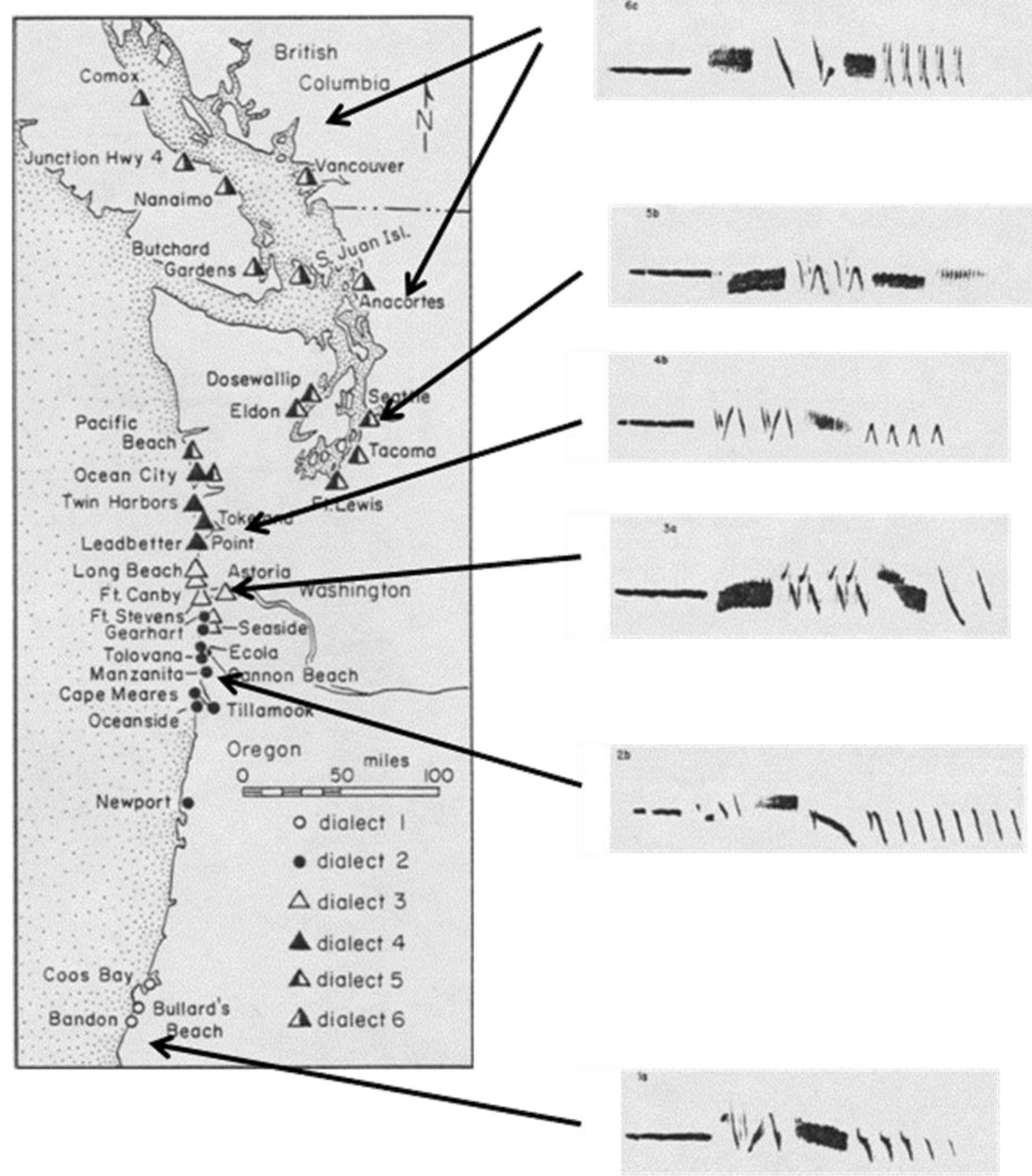

Figure 2. Dialect distribution in white-crowned sparrow along the west coast in North America (Baptista, 1977).

We will adopt here Mundinger's definition (1982): “a song dialect is a variant song tradition shared by members of a local population of birds, with a dialect boundary delineating it from other variant song traditions". Animal dialectal boundaries are more generally sharp, but some "hybrid" forms at the boundaries are known to occur in some species. Munidnger's definition implies that the shared vocal pattern results from "tradition" that is from social copying (i.e., learning from conspecifics) and hence eliminates the early descriptions of "dialects" in bees, now shown to be largely under genetic control and adapted to environmental conditions (Gould, 1982; Lindauer, 1977), but also questions the use of the term 
for species like the mole rat where dialects correspond to morphologically indistinguishable but genetically distinct species (Nevo, Heth, Beiles, \& Frankenberg, 1987). In lower vertebrates such as anuran amphibians, intraspecific variation in call characteristics are generally considered to be genetically inherited rather than transmitted culturally (Wycherley, Doran, \& Beebee, 2002). Therefore, we will here only refer to higher vertebrates.

\section{Birds and Other Animals}

It may seem surprising that the favored animal model for describing dialects and drawing parallels with human language is the songbird. Birdsong is a learned vocalization mostly transmitted through social influences (e.g., Snowdon \& Hausberger, 1997) and passes through developmental stages reminiscent of language development (Doupe \& Kuhl, 1999; Marler, 1970a). Song structure is often complex with different levels of organization: a single element, the note, being combined with others to build "syllables" organized in "phrases" (Brémond, 1968). Some species sing only one song type, but most have "repertoires", each bird having an array of several to many song types in its individual repertoire. Local variations can occur at the level of the note (e.g., chaffinch: Conrads, 1966; Marler, 1952; Promptoff, 1930; short-toed tree creeper Certhia brachydactyla: Thielcke, 1965) or of the whole song (e.g., Carolina chickadee Parus carolinensis, Ward, 1966; cardinal Cardinalis cardinalis, Lemon, 1966). Some descriptions of "subdialects" (e.g., variations of syllable structure in local groups within a main song dialect area) have occurred, leading to controversy about what could be called dialects, especially when applying the "isoglosses" method used for human dialects (Mundinger, 1982).

Dialects of European starlings, and the processes involved, are some of the best documented in the animal kingdom. European starlings form colonies (small groups of 8 to 10 neighboring nests 1 to $5 \mathrm{~m}$ apart), forage in groups varying from a few pairs to a hundred during the day, and gather in large communal roosts of several hundred to sometimes more than 1 million birds that spend the nights together (Feare, 1984). Birds visit their colony every day; it is really the basic stable social unit that is the center of all activities, and where neighboring males interact vocally, using loud simple whistles (AdretHausberger, 1982; Clergeau, 1993). Song is, however, present in all forms of gathering, forming choruses in the roosts, especially when the birds are settling for the night (Feare, 1984). Males sing more than females especially near the colony, where female song is rare (Henry \& Hausberger, 2001; Pavlova, Pinxten, Darras, \& Eens, 2007).

The song repertoire of each individual male in the field consists of loud simple whistles, some of which are "universal" (the Class 1 whistles) and are the basis for local dialects (Hausberger, 1997). In a first study performed on the university campus of Rennes, France, Hausberger and Guyomarc'h (1981) showed that all birds in the campus (nesting on buildings) shared the same variant for three of the class 1 whistles, but that each colony, composed of around 10 pairs, had its own variant of the "rhythmic theme" (Figure 3), that differed clearly from that represented in the other colonies, only a few hundred meters away. Additionally, variants of the other class 1 whistles sung by the campus birds differed from those recorded from another site, about $15 \mathrm{~km}$ away (Figure 3). These early findings led to a series of studies aimed at understanding how variants were distributed, under which influence, and for which function.

A more extensive study performed in the same area but on a larger scale focused on these other class 1 whistles. It appeared then that the different variants of each class 1 theme were not distributed randomly but followed a mosaic pattern delimiting dialectal areas where all birds sang the same variant that differed from the other nearby areas (Adret-Hausberger, 1983). At the boundaries, "bilingual" birds, using the two adjacent dialects, could be found. However, the remarkable finding was that each class 1 whistle type had its own pattern of variation, with dialectal areas covering 5 to $10 \mathrm{~km}^{2}$ for the "theme with inflexion," $150 \mathrm{~km}^{2}$ for the "harmonic" theme, several hundred of $\mathrm{km}^{2}$ for the simple theme that differed only in its total duration (Figure 3). 
A)
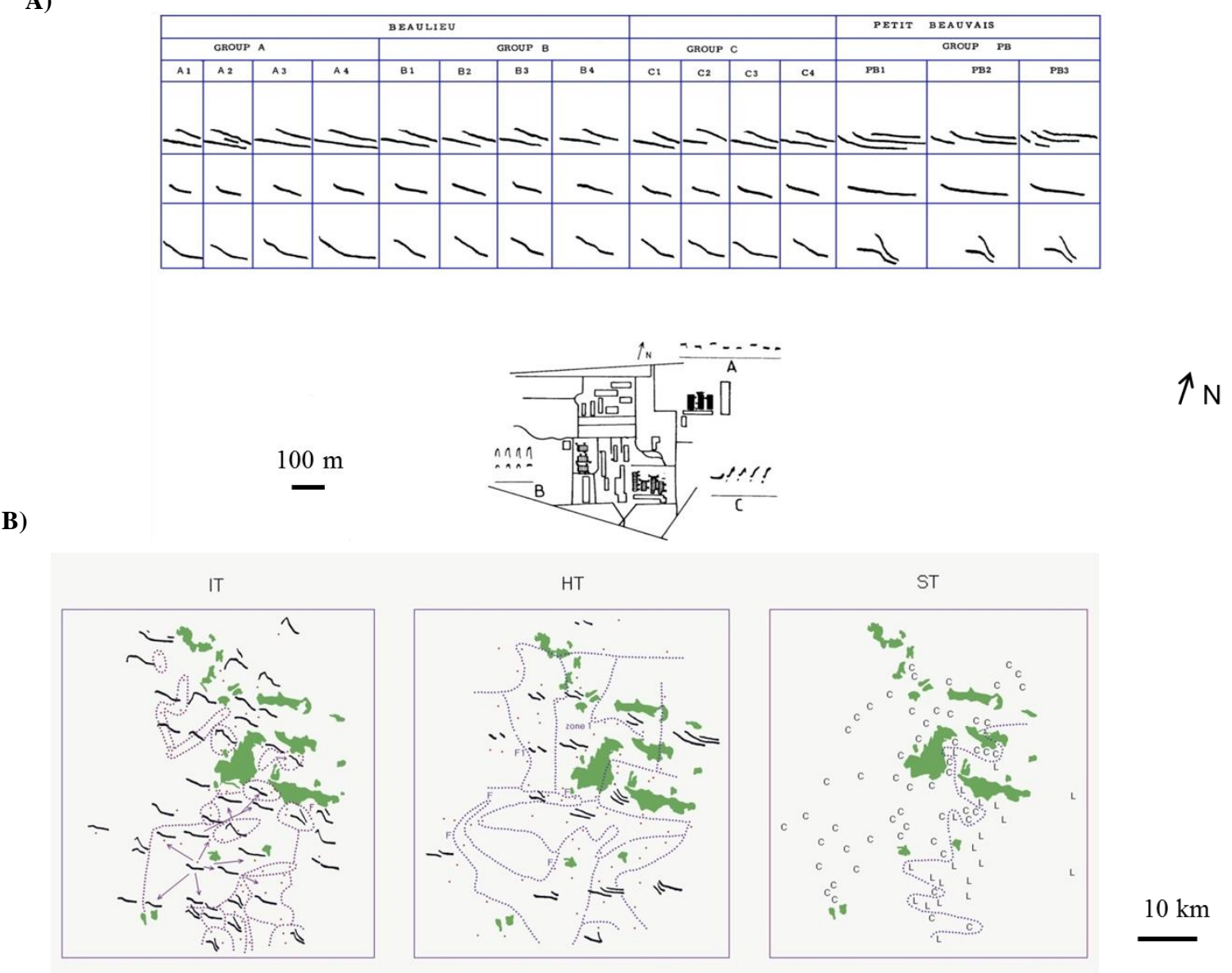

Figure 3. Complex dialectal system in the European starling observed in Rennes area. A) Comparison of class I themes (Inflection, Harmonic and simple themes) between colonies either on the same site (groups A, B, and C, $200 \mathrm{~m}$ apart) or further apart (15 km, Group PB). A map of site 1 (Rennes Campus University). The rectangles correspond to buildings where the nests are present (hatched or dark rectangles). The spectrograms correspond to the variant of the rhythmic theme sung by all members of the colonies considered, B) each map represents dialectal boundaries for the different types of class 1 whistles. Note the different level of variation for each type. IT, Inflection Theme, HT, Harmonic Theme, ST, Simple Theme and RT, Rhythmic Theme. In maps, dialectal boundaries correspond to dotted lines. The hatched areas correspond to forests. C, L, short versus long variant of ST (Hausberger, 1997).

Different levels of dialectal variations could thus be observed that did not share the same boundaries: each type had its own pattern of dialectal variation and two birds could share the same variant for one theme and not for another one. Dialectal boundaries occurred in adjacent areas without any visible habitat change that could explain a lack of transmission.

Furthermore, comparative studies in varied populations showed that unexploitable areas constituted barriers to the transmission of dialects suggesting that social exchanges are indeed necessary for dialect transmission (Adret-Hausberger, 1984). Social structure, influenced by the habitat, was found to strongly influence dialectal patterning. Thus, in a German population of starlings, the absence of nesting sites, and therefore of colonies, between villages, was associated with a lack of dialectal transmission (Adret-Hausberger \& Güttinger, 1984) whereas in Australia where nest opportunities were limited with individual nests instead of colonies, the dialectal system appeared much more limited with only two levels of variation (Adret-Hausberger, 1988). Finally, higher densities are associated with higher degrees of sharing (as opposed to the above mentioned Australian case) suggesting that dialects may increase tolerance between birds originating from the same social community, enabling them to have 
close contact in non-breeding and more "crowded contexts" such as roosts without increased aggression (Hausberger, 1997; Hausberger, Bigot, \& Clergeau, 2008).

There is in starlings no evidence that dialects may be the basis for assortative mating: dispersal of young depends mostly on nest availability, and younger animals are generally repelled by older birds (Clobert \& Berthet, 1983). Occasional reports of females pairing with their father or brother do occur but this is clearly not the rule (Flux \& Flux, 1981; Merkel, 1980). When kept together in large aviaries, females seem to pair with males independently of them being from the same geographic area or not (Hausberger, Richard-Yris, Henry, Lepage, \& Schmidt, 1995).

The finding that sharp boundaries could occur within a continuum of colonies shows that geographical variation cannot be a mere by-product of learning the songs of neighboring birds: social issues are necessarily at stake, and starling dialects are not a mere epiphenomenon of learning. Starlings tend to respond to the playback of whistles through a loudspeaker by using the same theme (e.g., an inflection theme in response to an inflexion theme broadcast), a phenomenon called song matching, that shows that in all cases (own or foreign variant), they do recognize the theme heard (a case of mutual intelligibility, that makes human speakers of two different dialect areas aware they are speaking the same language, according to Petyt, 1980) but they respond less often, after a longer latency, and fly away more easily if they hear a foreign dialect (Adret-Hausberger, 1982).

As mentioned before, gatherings, like foraging flocks and roosts, are places where birds originating from different nearby geographical areas mix and where song can be intensively produced: recordings at different locations within the roosts revealed that birds that shared the same dialectal variant tended to cluster suggesting an internal structuring of roosts corresponding to the "dialectal social units." Dialects may well be used as "passwords" that allow birds from the same geographical and social origin to settle together within these large assemblies. Indeed, the birds from the same colony do arrive together from the roost in the morning (Hausberger, Bigot, \& Clergeau, 2008).

Few other groups share this vocal plasticity, and despite the close proximity of primates to humans, they constitute one of the less comparable groups with respect to learning and vocal plasticity. Some studies show that young non-human primates reared in isolation are able to produce normal calls (Winter, Handley, Ploog, \& Schott, 1973) and that the genetic influence on vocal production is probably high (Hammerschmidt \& Fisher, 2008; Owren, Dieter, Seyfarth, \& Cheney, 1992). No wonder therefore that mention of "dialects" in primates is rare in the scientific literature. Nevertheless, acoustic divergences between populations or groups have been described (Japanese macaques Macaca fuscata, Green, 1975; tamarins Saguinus l. labiatus, Maeda \& Masataka, 1987; marmosets Cebuella pygmaea, De la Torre \& Snowdon, 2009). De la Torre and Snowdon (2009) qualify "interpopulation differences in the physical structure of two separate vocalizations" as dialect. And there is some evidence that these differences are not genetically but socially determined: neighboring chimpanzee groups are more acoustically divergent than geographically distant groups, suggesting that social learning has acted on group differentiation (Crockford, Herbinger, Vigilant, \& Boesh, 2004). In Japanese macaques, the vocal characteristics of the population seem to be progressively acquired by juveniles during development as a result of social convergence (i.e., learning) (Tanaka, Hideki, \& Masataka, 2006). In mouse lemurs, acoustically dimorphic advertisement calls separate morphologically and genetically homogenous populations (Hafen, Neveu, Rumpler, Wilden, \& Zimmermann, 1998) and these modifications in acoustic structures do not rely on a maturational process. Innovation may occur, where individuals start producing new sounds. This has been described in captive animals that tried to attract human attention (chimpanzee, Hopkins, Taglialatela, \& Leavens, 2007) or developed a new form of alarm call specific to the approach of the caretaker (Campbell's monkey, Lemasson, Richard, \& Hausberger, 2004; Ouattara, Zuberbühler, N'goran, Gombert, \& Lemasson, 2009). This innovation may have been socially transmitted as all group members had it which indicates a learning process. Innovation has been little studied as a potential source of geographical variation, but more recent studies suggest that plasticity is higher than originally thought: local variations may well have been underestimated in primates (Koda et al., 2013; Lemasson, Ouattara, Petit, \& Zuberbühler, 2011; Slocombe \& Zuberbühler, 2007). Acoustic variations in terrestrial mammals in general are usually considered to be limited to individual variation that is potentially learned 
perceptually by group members, but that reflects gross characteristics such as body size (Lemasson, Boutin, Boivin, Blois-Heulin, \& Hausberger, 2009; Lemasson, Mikus, Blois-Heulin, \& Lodé, 2014; Reby \& McComb, 2003) or arousal state (Lemasson, Remeuf, Rossard, \& Zimmermann, 2012), suggesting a lack of control on production characteristics. There are some indications of learned vocalizations in elephants, goats and gazelles (Briefer \& McElligott, 2012; Poole, Tyack, Stoeger-Horwath, \& Watwood, 2005; Volodin, Volodina, Lapshina, Efremova, \& Soldatova, 2013). Kangaroo rats may also alter their foot drumming signatures under social pressures (Randall 1994, 1995). A recent study, furthermore, indicated that rock hyraxes (Procavia capensis) are able to learn syntactic structures through social transmission leading to geographical dialects (Kershenbaum, Ilany, Blaustein, \& Geffen, 2012). Dialect in rock hyraxes can therefore be defined as: "hyraxes in different regions of the country sing a repertoire of song that is substantially different from the syntactic repertoire of other regions."

Physical constraints are a potential source of individual variation. Thus morphology of the skull, beak opening may vary between animals and be a source of variation in pitch as are for some mammals the body size for example (barnacle goose Brenta leucopsis, Hausberger, Black, \& Richard, 1991; macaques, Fitch \& Hauser, 1995; horses, Equus cabalus, Lemasson et al., 2009) but this cannot explain the sometimes rapid changes observed in vocal convergence between animals. Moreover, the phonation organ of songbirds (syrinx), based on cartilages located at the junction between the primary bronchi and the trachea and, regulated by up to 7 pairs of muscles that control the air flow very precisely (Hausberger, Cousillas, George, \& Henry, 2002; Suthers \& Margoliash, 2002) provides them with a high level of flexibility to copy and learn new songs as does their well-known brain developmental plasticity (Arnold, 1992; Nottebohm, 1989). This is why some species of birds may even convincingly mimic human speech (e.g., starlings, West \& King, 1990).

Terrestrial mammals, including non-human primates, seem to have much less capacity for control over their sound production system, both at the peripheral and central levels (Hammerschmidt \& Fischer, 2008). Vocalizations are mostly simple in structure as compared to most bird songs. Nonetheless, in some mammals, acoustic variations may rely upon learning processes. Vocal dialects have been identified in the echolocation signals of different species of bats (Davidson \& Wilkinson, 2002; Esser \& Schubert, 1998), known for some abilities in vocal learning (Boughman, 1998). Interestingly, marine mammals rival songbirds, showing a plasticity that enables them even to mimic artificial sounds or human speech like the well-known "Hoover," a captive elephant seal (Hiss, 1983; Schustermann, 2008) or beluga (Eaton, 1974; Ridgway, Carder, Jeffries, \& Todd, 2012). The vocal tract of these species obviously enables an extensive control over sound production and adaptation to others characteristics such as breath control for example (Schustermann, 2008). Vocal dialects have been identified in seven species of pinnipeds (Tyack \& Miller, 2002), in particular in elephant seals (Le Bœuf \& Peterson, 1969). In Cetaceans, social structure has an important influence on vocal variations (Rendell \& Whitehead, 2001; Tyack, 1986). In sperm and killer whales, stable matrilineal groups (pods) have specific vocal repertoires called dialects; when pods share a portion of their call repertoires, they are called vocal clans (Ford, 1991; Riesch, Ford, \& Thomsen, 2006). Vocal dialects have been shown to be stable over 30 years at least (Ford, 1991) although some subtle changes can occur over time (Deecke, Ford, \& Spong, 2000). Interestingly, distinct acoustic repertoires persist in the form of distinct acoustic clans despite frequent acoustic contacts between members of different clans (Deecke et al., 2000). There is a selective copying of signals between group members (Kremers, Lemasson, Almunia, \& Wanker, 2012; Yurk, Barrett-Lennard, Ford, \& Matkin, 2002). Since clans correspond to maternal lineages, this copying is more likely to occur between maternally related individuals. In the estuarine dolphins, geographical variations have been found on a large scale, revealing a continuum of variation with more divergence at both ends of a 4000 kilometers transect (Rossi-Santos \& Podos, 2006).

Intra specific variations in vocalizations are therefore observed in a number of animal species. More precisely, dialectal variations are especially salient in species showing learning and vocal plasticity such as birds or marine mammals, characterizing groups of socially related animals. 


\section{The Ontogeny of Dialects}

Vocal learning again has been best studied in songbirds, despite the fact that field data are mostly missing. Young birds fly away when becoming independent from parents and in the best case researchers occasionally find them again at adult stages. When this is the case, these birds sing systematically a different dialect from their father (e.g., Darwin's finches, Grant, 1984; saddlebacks, Jenkins, 1978), the same (e.g., white-crowned sparrows, Baker \& Cunningham, 1985), or either one or the other (Petrinovitch, Patterson, \& Baptista, 1981). Songbirds show developmental stages that start for most species a few weeks after hatching with subsong, a very rudimentary continuous vocalization (sometime compared to babbling, Marler, 1970b), they refine it into a "plastic song" that is closer to real song in their second year, and reach a full adult song weeks before the onset of the breeding season.

Experimental settings have shown that some species have an early sensitive period for learning song (10 to 50 days of age in white crowned sparrows) despite producing that song themselves much later. Timing of learning varies considerably between species up to "open ended learners" that can learn new songs throughout their lives (Baptista \& Gaunt, 1997).

Some principles seem common throughout birdsong learning: songbirds need intact hearing of the acoustic forms of the song variants they will learn, and they show an early selectivity towards the species song. Selectivity is further ensured through social learning: the young bird can learn from its feeding father (Bullfinches, Pyrrhula pyrrhula), from its father and other adult members of the group (zebra finch, Taeniopygia guttata), from the same-sex adults (Indian hill mynah, Gracula religiosa), or unrelated adults when entering breeding condition (Baptista \& Gaunt, 1997). Some "horizontal transmission" between same-age young also occurs when adults are missing or in lower density but the resulting song is less well structured. Most young songbirds stay in groups of juveniles for several months after dispersal from the natal area. This may be a way of stimulating vocal production (Bertin, Hausberger, Henry, \& Richard-Yris, 2007; Freeberg \& White, 2006). Whether early or late learning are concerned, all studies converge toward a major role for social transmission. Indeed, especially in social species but event in territorial species, individuals interact on a regular basis and end up having expectations about the other's behavior, which is in accordance with Hinde's (1976) definitions of a relationship. Thus, neighboring territorial songbirds react less to the playback of known neighbors than towards strangers and dialects of neighbors do arise even in these species (Briefer, Aubin, \& Rybak, 2011; Falls, 1982). In social species, social bonding (positive relationship) between particular individuals is an important source of copying (Hausberger et al., 1995; Poirier et al., 2004). Social interactions may overcome inhibitions and enable learning outside sensitive periods or between species (Pepperberg, 1997). Strong bonds between young may even prevent not only proper learning from adult song (Bertin et al., 2007; Bertin, Hausberger, Henry, \& Richard-Yris, 2009; Poirier et al., 2004), but also a proper development of sound processing in the brain, as in the European starling (Cousillas, George, Henry, Richard, \& Hausberger, 2008; Cousillas, Mathelier, Richard, Henry, \& Hausberger, 2006; Cousillas et al., 2004).

Social relationships are therefore essential not only for learning dialects in conformity with the local group but also to be able to perceive songs and its variations, a situation that reminds one of perceptual difficulties second language speakers have in perceiving subtle phonetic details (Strange \& Jenkins, 1978).

It has been suggested that dialects may originate from young birds in a low adult/young ratio developing innovations, or from errors through learning that would be further transmitted. In most species with high social mobility or with strong social bonds, however, adult plasticity ensures adaptability to social changes. Social bonding is then the basis for local conformity as in the case of dolphins (Tyack \& Sayigh, 1997), starlings (Hausberger et al., 1995) or Campbell monkeys (Lemasson, Richard, \& Hausberger, 2004). The individual throughout development, including adulthood, is immersed in a diversity of social influences, where selective attention through bonding will ensure social and vocal adaptability (Snowdon \& Hausberger, 1997). 


\section{Origin and Function of Dialects in Animals}

The avian dialect studies promoted the idea that dialects may contribute to reduce gene flow between individuals of neighboring dialects by assortative mating, the females choosing a mate that sings the same dialect as their father. The hypothesis was this would lead to adaptations of dialectal populations to local environmental conditions (Marler \& Tamura, 1962). This also presupposed that young males remained in their natal area and learned the local dialect. Since then, many examples of species that did not fit with this proposal have emerged, and the three hypotheses to explain dialects proposed by Payne (1981) remain valid options:

- The "historical model," where dialects would be an epiphenomenon of the tendency to learn in songbirds. Dialects would be the consequence of dispersal, copying errors and colonization of new habitats and could correspond to either scattered patches or gradual shifts over a transect.

- The racial specialization" model, corresponding to the Marler and Tamura (1962) proposal. Dialects would favor the emergence of local populations adapted to the local conditions. This model requires that 1) dialectal populations show genetic distinctiveness, 2) juvenile dispersal is infrequent, 3) assortative mating occurs through female choice. This model could be considered as a sort of "habitat adaptation model.

- The "social adaptation model" where dialectal areas would correspond to social entities, young would disperse from one area to another and then learn the local songs, social interactions would differ within and between dialect communities.

The historical and racial models suppose a rather stability of the local variations while the social model predicts large and sudden changes by individuals in response to social changes.

\section{Dialects as an Epiphenomenon?}

Animal dialects have been also considered as a by-product of learning with no particular function (Andrew, 1962; Podos \& Warren, 2007; Wiens, 1982). Different cultural evolutionary models have been used to test this hypothesis in birds (Lachlan, 2008). Slater, Ince, and Colgan (1980) used a statistical method derived from population genetics and estimated that cultural mutation and immigration occurred at a rate that matched an analysis of historical patterns of song change. Further modeling led to the conclusion that this estimate was due to immigration (Lachlan \& Slater, 2003). These authors concluded that their study bird, the chaffinch, had no strategy of song learning that would regulate the geographic distribution of variants.

Geographical variations in bird vocalizations may also be the consequence of habitat constraints and propagation of sounds in the atmosphere (Wiley \& Richards, 1983). The sound signal is degraded during transmission and this degradation (type and amount) differs according to the environmental conditions (foliage, temperature for example). Some large scale variations have been shown to relate to adaptations to environmental constraints on transmission: the trills of Zonotrichia capensis vary between forest and plain areas (Handford \& Nottebohm, 1976) as do the songs of great tits (Hunter \& Krebs, 1979). Local dialect boundaries however rarely coincide anyway with "habitat boundaries" (Hansen, 1985). A few noticeable cases of adaptation to local noise are worthwhile mentioning, such as variations of frequency or temporal characteristics of calls of bottlenose dolphins, belugas (Rendell, Matthews, Gordon, \& MacDonald, 1999) and marmosets (Brumm, Katerin, Köllmer, \& Todt, 2004) in response to background noise, and of birds in urban environment that tend to sing at higher frequencies, above the traffic noise (Leader, Wright, \& Yom-Tov, 2005). Such effects may account for some local variations and have to be kept in mind. However, none of these adaptations leads to identifying clear dialectal groups that would be separated by clear sharp dialectal boundaries. 


\section{Genetic Differentiation}

Although genetic adaptation has been repeatedly proposed to account for variation in animal vocalizations, stressing the role of dialect differentiation in selective mating and territoriality (Baker \& Cunningham, 1985; Nottebohm, 1969), the link between vocal and genetic structures remains questioned (Leader et al., 2008). No relation was found between local dialects and DNA patterning in populations of orange-tufted sunbirds Cinnyris oseus (Leader et al., 2008), parakeets Amazona auropalliata (Wright, Rodriguez, \& Fleischer, 2005) or rufous collared sparrows Zonotrichia capensis (Lougheed, Handford, \& Baker, 1993).

Despite numerous attempts to identify female preferences based on dialects, evidence is again scarce and contradictory. Female white crowned sparrows may be more attracted and stimulated by the local dialect (Baker, Spitler-Nabors, \& Baker, 1981; Spitler-Nabors, \& Baker, 1983), but whether or not the mate's dialect corresponds to the natal dialect and whether this choice is systematic has never been clearly established (Petrinovitch \& Baptista, 1984; Petrinovitch, et al., 1981). In indigo buntings, females choose their mates independently of their dialects but may prefer those that "conform" most to the local songs (Payne, Payne, \& Rowley, 1988; Payne \& Westneat, 1988).

In contrast to this proposed model, mating in killer whales is absent within the same dialect community, while it occurs mostly between different vocal clans (Yurk et al., 2002). Female Darwin's finches and saddlebacks actively choose a partner that has a different dialect from their father, consequently avoiding inbreeding with their male siblings (Grant, 1984).

\section{Social Adaptation}

According to Mundinger (1982), "specific song dialects are animal cultures that may serve socially useful functions" (p. 197). Thorpe and North (1965) proposed that the imitative ability observed occurs when the main function of song is to provide for social recognition and cohesion. For Janik and Slater (1997), the need for individual recognition and group cohesion was the most likely selection pressure for the evolution of vocal learning in dolphins. Social transmission of dialects may be the rule in songbirds, bats, marine mammals and probably these primate species that show variations.

Overall, birds respond differentially to the playback of the local versus a distant song variant. Most species respond more (approach, song or attentional behavior) to the local dialect (e.g., Darwin's finches, Grant, 1984; Podos, 2007; satin bowerbirds Ptilonorhynchus violaceus, Nicholls, 2008; wrens Troglodytes troglodytes, Kreutzer, 1974; white crowned sparrows, Tomback, Thompson, \& Baker, 1983; orange tufted sunbird, Leader, Wright, \& Yom-Tov, 2002; yellow-naped amazon Amazona auropalliate, Wright \& Dorin, 2001; brown headed cowbirds Molothrus ater, Dufty \& Hanson, 1999; Freeberg, King, $\&$ West, 2001). White crowned sparrows sing more in response to the local dialect but have more aggressive reactions towards the distant dialect (Petrinovitch \& Patterson, 1981), leading to the conclusion that vocal sharing may reduce aggression between close neighbors (Briefer, Rybak, \& Aubin, 2008). In killer whales, the calls that serve as dialectal signatures are most frequently produced when the animals are feeding far apart or when two pods meet, suggesting that they serve the function of keeping contact between pod members and ensuring cohesion (Ford, 1989; Thomsen, Franck, \& Ford, 2002). Birds from different breeding areas, where dialects are generally identified, may mix in different contexts, such as the foraging grounds in winter (white crowned sparrows, Tomback et al., 1983), or the communal night roosts where birds spend the night (caciques, Feekes, 1982), all sorts of gatherings that may require vocal "markers" to ensure identification of populations or groups. Despite these interdialectal encounters, birds, like whales, do maintain their own variants in these contexts as they do during playback experiments (e.g., Dufty \& Hanson, 1999). One main function may be advertising social identity. In some cases, vocal sharing enables advertisement of group membership in animals that spend time together regularly such as flocks of black-capped chickadees, Poecile atricapillus (Ficken \& Ficken, 1984), roosts of yellow-naped amazon (Wright, 1996) or breeding groups of humpback whales (Noad et al., 2000) or 
caciques (Trainer, 1989). Changes in these groups may lead to rapid changes of dialects (Noad et al., 2000; Nowicki, 1989).

In animals, calls or songs do not change function either as a result of dialects. Variation is greater in affiliative vocalizations such as contact calls than in other types of vocalizations such as alarm calls (Bouchet, Blois-Heulin, \& Lemasson, 2013; Lemasson \& Hausberger, 2011; Snowdon, Elowson, \& Roush, 1997). In the contact calls of Diana monkeys, for example, the degree of acoustic individual distinctiveness is context-dependent. Females produce individually-distinctive call structures when travelling in a dark habitat (facilitating spatial cohesion), whereas females acoustically converge with one another when interacting vocally (facilitating social cohesion) (Candiotti, Zuberbühler, \& Lemasson, 2012). From this perspective, animal and human studies are both concerned with understanding the social context of variation and change.

\section{Dialects in Human and Animals: What Parallels}

Description of dialects in human and animals show numerous common points in the form but also in the way this vocal variations are link to social life. To go further in establishing parallels, it appeared that the dynamic of dialect changes rely on the same social constrains and that the complex social life of human groups and some animals' species may explain complex vocal sharing patterns. The social function of dialect appeared therefore robust in both human and animals. On the other hand, counteradaptivity of vocal variations still raised questions in the sense that in both groups, dialects are strong social markers and may at some point lead to misunderstanding.

\section{Mobility and Change}

The most mobile groups of species are also those that show the greatest ability to change their vocal structure rapidly (e.g., dolphins), which is much less marked in the very stable groups of primates for example. Dolphins, like many species of songbirds, can show rapid changes in the structures of their whistles when faced with social changes (Tyack \& Sayigh, 1997). Chickadees can change dialects in a week if group membership changes (Nowicki, 1989). Therefore, animals are prepared when necessary to respond to changes in their social environment by marked vocal plasticity. Conditions ranging from the very stable dialectal variations (found again 30 years later) of white crowned sparrows (Chilton \& Lein, 1996) and Darwin's finches (Goodale \& Podos, 2010) or killer whales (Deecke et al., 2000), to the rapid changes every breeding season of caciques (Trainer, 1989) or humpback whales (Eriksen, Millar, Tougaard, \& Helweg, 2005), show that animal dialects encompass a wide diversity of features and processes.

In humans, after a primary focus in traditional dialectology on non-mobile, rural, often old men (selected as characteristic of their regional community), human dialect studies have moved on towards more mobile, urban speakers from various social categories (Chambers, 1992; Chambers \& Trudgill, 1998) with a renewed interest in dialect contact and language change (Milroy, 2002; Trudgill, 1986). Mobility has long been considered as a powerful leveler of traditional local forms, leading to the question of the persistence of linguistic diversity given the increasing mobility of speakers within sociogeographical space. However, in contact situations, where an innovative form starts to interact with a traditional local form, a number of potential outcomes emerge (Britain, 2002): adoption of the innovation, the emergence of interdialect forms between the local form and the innovation (e.g., formation of new dialects in new towns, Corby, Dyer, 2002; Milton Keynes, Kerswill \& Williams, 2000), or the rejection of the innovation including the reinforcement of the local dialect (e.g., Martha's Vineyard, Labov, 2001). Although vernacular maintenance and resistance against dialect leveling seem to be favored by the stability and the insularity of speech communities, isolated communities with close-knit networks may also be linguistically innovative and heterogeneous with rich intra-dialectal variation, contrary to assumption (Schilling-Estes, 2002). Beyond geographical mobility, social and occupational mobility also favors the spread of a linguistic form among speech communities. Most studies of linguistic change in 
progress show that the innovators of change are mobile speakers more often located centrally in the social spectrum (i.e., upper working class and lower middle class), and mostly upwardly mobile women (Chambers, 2003; Labov, 2001; 2002; Milroy, 2002).

On the other hand, according to the principle of density (Bloomfield, 1933; Labov, 2001), the more often people talk to each other, the more similar their speech will be. Thus social network effects may also be a mechanical result of differences in frequency of interaction with speakers of local dialects. While human speech shows strong frequency effects and can be influenced by ambient dialect through unintentional imitation, it does not seem necessary to invoke systematically high-order sociopsychological factors (Delvaux \& Soquet, 2007). In some songbirds, higher densities were also associated with more vocal sharing and less individual diversity (Motis, 1994).

Some bird species present different levels of social encounters and can at times be involved in groups that can count more the one million of individuals (e.g., night roosts). However, this is precisely the situation where small cohesive social units may need to remain cohesive within the large assemblies.

\section{Could Dialects be Counteradaptive?}

The successive theoretical accounts of the adaptive function of human linguistic variation have been discussed in detail by Chambers (2003). Given the universality of linguistic variation, it has long been considered that it has no adaptive function, or even that linguistic diversity is counteradaptative, leading to misunderstanding in communication, social stigmatization (i.e., overt negative value associated with nonstandard dialects), and social integration difficulties. Yet linguistic diversity endures beyond social pressures and prejudices against nonstandard dialectal varieties. Chambers $(1985 ; 2003)$ introduced a clear-cut distinction between global counteradaptivity and local adaptability by pinpointing the effects of language acquisition within the natal setting of the family and of the local dialect, and the effects of mobility (geographical, social and occupational) in global counteradaptivity when mobile individuals encounter dialect groups different from their native group. Empirical evidence shows that young children show dialectal patterns similar to those of their caregivers, supporting the importance of family in early dialect acquisition (Barbu et al., 2013; Chevrot et al., 2011; Smith, Durham, \& Fortune, 2009). As they grow up, children from non-native families tend towards the dialectal uses of the local speech community, showing a break between family and peer group influence during middle childhood and adolescence (Kerswill \& Williams, 2000; Labov, 2001; Roberts, 2002). However, second dialect acquisition abilities seem to be reduced during adulthood (Chambers, 1992; Kerswill \& Williams, 2000), at least unless high social motivation and close social ties within the new dialect setting drive convergence toward the local dialect forms. Therefore, most humans carry regional and social linguistic markers from their native community. These markers have a local adaptability, namely significance for speakers' local identity and relationships (Chambers, 1985, 2003), as we will see with dialects within social networks in particular.

In animals, it has been demonstrated that individuals (newcomers) that were able to modify their song to adapt to the local social vocal characteristics received less aggression from the resident males (Burt \& Beecher, 2008) and to increase the chances of mating (Payne et al., 1988). Young white crowned sparrows may also modify their song at later stages in order to reduce aggression from resident local males (Petrinovitch, 1988). Not conforming may indeed be counteradaptive. In the same way, killer whale calls seem to be acquired from kin while dolphins show convergence patterns in their whistles that reflect social bonding (Tyack, 2000). Coalitions of males can thus emerge (Smolker \& Pepper, 1999), that may be based in part on these learned whistle patterns. Learning in delphinid species obviously results from social bonds (Mc Cowan \& Reiss, 1997). Recent studies on Campbell's monkeys have shown unexpected plasticity in their calls as a result of social affiliation. Females within a social group develop variants that are shared with preferential social partners (Lemasson \& Hausberger, 2004), regardless of any genetic proximity (Lemasson et al., 2011).

Social dynamics resulted in corresponding vocal changes with drastic modification when sudden social changes were introduced. More socially distant animals showed more difference in their call structures. Playback experiments confirmed that animals can discriminate between old versus new or 
unknown variants (Lemasson, Zuberbühler, \& Hausberger, 2005). Thus, social groups may have a "group signature," where all members share the same form of vocalization and show clear coalitions towards other members of their own groups. This is the case for Australian magpies where groups of birds separated by only a line of trees can have markedly different songs and show territorial defense against neighboring groups (Brown \& Farabaugh, 1997).

Another common point between birds and human concern their capacity to recognize and to accept interlocutors as valuable partners. In animal, geographical variations in some species, but not all, follow a continuum, leading to more differentiation at its two ends (Hunter \& Krebs, 1979). This is also observed in humans, where in some cases (but not all) the greater the distance, the greater the difficulty of understanding (Chambers \& Trudgill, 1998). However, like human speakers from two different dialect areas who have a kind of mutual intelligibility that makes them aware they are speaking the same language (Petyt, 1980), birds do recognize song types despite dialectal variations (see starlings AdretHausberger, 1982).

Interestingly, the distinction made by different authors (Mundinger, 1982) between macrogeographic and dialectal variations in songbirds might be an interesting line of investigation also in humans, especially if one considers that more evidence of genetic or habitat influences are found for large scale variations in birds than for dialects obviously more related to social exchanges (Payne, 1981).

Several human-animal parallels concerning the development, the form and the function of dialects have been raised here. However, most of the aforementioned examples concern phonological, hence nonlexical, dialects. In humans, dialects, as well as languages (for more extreme geographical variations), also differ from one another semantically. This is a potential challenge for future comparative studies with animals. In line with that, some promising findings have been recently published, notably in nonhuman primates. Call culture has been proposed in orangutans after comparing communicative behaviors of different populations in standardized contexts (Wich et al., 2012). Populations differ from one another by calling or not in these contexts, or by emitting different call types. Semantic dialects have also been proposed in Campbell's monkeys where populations from Ivory Coast and Sierra Leona, exposed to different levels of predator threat, differ in the contextual usage of the same alarm call types (Schlenker et al., 2014). At last, examples of call innovation, associated to new meanings, were found in captive groups of chimpanzees (food call to attract human attention, Hopkins et al., 2007) and Campbell's monkeys (alarm call to alert for human presence, Ouattara et al., 2009).

\section{Conclusion: Converging Solutions to Converging Problems?}

Several topics were originally highlighted by Snowdon and Hausberger (1997): the greatest vocal learning abilities are found in species with the greatest mobility (birds, marine mammals) as individuals are likely to encounter other conspecifics from different geographic origins. Animals living in stable groups may have less reason to show plasticity in their vocal structure and subtle adjustments may be enough to adapt to subtle social changes. The hypothesis that vocal variants could be the basis for "social badges" has been proposed at all phylogenetic levels where vocal sharing occurs. All the evidence produced here shows that contrary to Chambers' (2003) suggestion that the high mobility, vocal accommodation abilities, and rapid code-switching found in humans had no counterpart in animal species these characteristics may well have led both humans and animals to evolve vocal plasticity, social learning abilities, and a high sensitivity to social bonding, to the point that even brain processes may be altered (Cousillas et al., 2006, 2008).

Preferential bonding between individuals may furthermore lead to progressive changes at a larger scale. The diffusion of dialectal varieties across socio-geographical space involves contact and accommodation (Britain, 2002), stressing a major role of face-to-face interactions and speakers' accommodation during exchanges in dialect formation and change (Pardo, 2006). Individual short-term accommodation may become a long-term accommodation that may in turn spread throughout the community at large (Trudgill, 1986). Accommodation is the way in which individuals adjust their communication behaviors to one another, either to become more alike (convergence) to promote liking 
and facilitate interactions, or to exaggerate their differences (divergence) to distance oneself from the interlocutor (maintenance) (Shepard, Giles, \& Le Poire, 2001). This may well be the shared key characteristic in the development of dialects in both animals and humans.

\section{Acknowledgments}

We are grateful to Pr Adrian Craig and to Ann Cloarec for improving the English of this manuscript and to F. Joubaud for her help with the literature. We thank Paul Foulkes, Jean-Pierre Chevrot and Todd Freeberg for their comments on this manuscript.The studies benefitted from funding from the CNRS through specific programs ("Origine du Langage et des Langues"), and from Rennes1 University.

\section{References}

Adret-Hausberger, M. (1982). Social influences on the whistled songs of starlings. Behavioral Ecology and Sociobiology, 11, 241-246.

Adret-Hausberger, M. (1983). Variations dialectales des sifflements de l'étourneau sansonnet sédentaire en Bretagne. Zeitschrift für Tierpsychologie, 62, 55-71.

Adret-Hausberger, M. (1984). Variations dialectales et "barrières naturelles" chez l'étourneau sansonnet (Sturnus vulgaris). Biology of Behaviour, 9, 213-225.

Adret-Hausberger, M. (1988). Song differentiation and population structure: The example of the whistled songs in an introduced population of European starlings Sturnus vulgaris in Australia. Ethology, 79, 104-115.

Adret-Hausberger, M., \& Güttinger, H. R. (1984). Constancy of basic pattern in the songs of two populations of starlings: A comparison of song variation between sedentary and migratory populations. Zeitschrift für Tierpsychologie, 66, 309-327.

Andrew, R. J. (1962). Evolution of intelligence and vocal mimicking. Science, 137, 585-589.

Arnold, A. P. (1992). Developmental plasticity in neural circuits controlling birdsong: Sexual differentiation and the neural basis of learning. Journal of Neurobiology, 23, 1506-1528.

Baker, M. C., \& Cunningham, M. A. (1985). The biology of bird-song dialect. Behavioural and Brain Sciences, 8, 85-133.

Baker, M. C., Spitler-Nabors, K. J., \& Baker, M. S. A. (1981). Early experience determines song dialect responsiveness of female sparrows. Science, 214, 819-820.

Baptista, L. F. (1977). Geographic variation in song and dialects of the Puget Sound white-crowned sparrow. Condor, 79, 356-370.

Baptista, L. F., \& Gaunt, S. L. L. (1997). Social interaction and vocal development in birds. In C. T. Snowdon \& M. Hausberger (Eds.), Social influences on vocal development (pp. 23-40). Cambridge, UK: Cambridge University Press.

Barbu, S., Nardy, A., Chevrot, J. P., \& Juhel, J. (2013). Language use and evaluation during early childhood: Adhesion to social norms or integration of environmental regularities? Linguistics, 51, 381-411.

Benedict, L., \& Bowie, R. C. K. (2009). Macrogeographical variation in the song of a widely distributed African warbler. Biology Letters, 5, 484-487.

Bergman, G. (1980). Die veränderung der gesangmelodie der kohlmeise Parus major in Finnland and Schweden. Ornis Fennica, 57, 97-111.

Bertin, A., Hausberger, M., Henry, L., \& Richard-Yris, M. A. (2007). Different social constraints on the development of song features in starlings. Developmental Psychobiology, 49, 362-374.

Bertin, A., Hausberger, M., Henry. L., \& Richard-Yris, M. A. (2009). Adult/young ratio influences song acquisition in female European starlings (Sturnus vulgaris). Journal of Comparative Psychology, 123, 195-205.

Bertram, B. (1970). The vocal behaviour of the Indian Hill Mynah Gracula religiosa. Animal Behaviour Monograph, 3, 79-192.

Bloomfield, L. (1933). Language. Chicago: University of Chicago Press.

Bouchet, H., Blois-Heulin, C., \& Lemasson, A. (2013). Social complexity parallels vocal complexity: A comparison of three nonhuman primate species. Frontiers in Psychology, 4, 390.

Boughman, J. W. (1998). Vocal learning by greater spear-nosed bats. Proceedings Royal Society of London B, 265, 227-233.

Bowman, R. I. (1979). Adaptive morphology of song dialects in Darwin's finches. Journal of Ornithology, 4, 353389. 
Brémond, J. C. (1968). Recherches sur la sémantique et les éléments vecteurs d'information dans les signaux acoustiques du rouge-gorge (Erithacus rubecula L.). Terre Vie, 2, 109-220.

Briefer, E., Aubin, T., \& Rybak, F. (2011). Response to displaced neighbours in a territorial songbird with a large repertoire. Naturwissenschaften, 96, 1067-1077.

Briefer, E. F., \& McElligott, A. G. (2012). Social effects on vocal ontogeny in an ungulate, the goat, Capra hircus. Animal Behaviour, 83, 991-1000.

Briefer, E., Rybak, F., \& Aubin. T. (2008). When to be a dear enemy: Flexible acoustic relationships of neighbouring skylarks, Alauda arvensis. Animal Behaviour, 6, 1319-1325.

Britain, D. (2002). Space and spatial diffusion. In J. K. Chambers, P., Trudgill \& N. Schilling-Estes (Eds.), The handbook of language variation and change (pp. 603-637). Oxford: Blackwell.

Brown, E. D., \& Farabaugh, S. M. (1997). What birds with complex social relationships can tell us about vocal learning: Vocal sharing in avian groups. In C. T. Snowdon \& M. Hausberger (Eds.), Social influences on vocal development (pp. 98-127). Cambridge, UK: Cambridge University Press.

Brumm, H., Katerin, K., Köllmer, I., \& Todt, D. (2004). Acoustic communication in noise: Regulation of call characteristics in a New World monkey. The Journal of Experimental Biology, 207, 443-448.

Burt, J. M., \& Beecher, M. D. (2008). The social interaction role of song in song sparrows: Implications for signal design. Comparative Cognition and Behavior Reviews, 3, 86-98.

Campbell-Kibler, K. (2009). The nature of sociolinguistic perception. Language Variation Change, 21, 35-156.

Chambers, J. K. (1985). Social adaptiveness in human and songbird dialects. Behavioral and Brain Sciences, 8, $102-104$.

Chambers, J. K. (1992). Dialect acquisition. Language, 68, 673-705.

Chambers, J. K. (2003). Sociolinguistic theory: Linguistic variation and its social significance. $\left(2^{\text {nd }}\right.$ ed.). Oxford: Blackwell.

Chambers, J. K., \& Trudgill, P. (1998). Dialectology (2 $2^{\text {nd }}$ ed.). Cambridge: Cambridge University Press, UK.

Chevrot, J. P., Nardy, A., \& Barbu, S. (2011). Developmental dynamics of SES-related differences in children's production of obligatory and variable phonological alternations. Language Sciences, 33, 180-191.

Candiotti, A., Zuberbühler. K., \& Lemasson. A. (2012). Convergence and divergence in Diana monkey vocalisations. Biology Letters, 8, 382-385.

Chilton, G., \& Lein, M. R. (1996). Long-term changes in songs and song dialect boundaries of puget white-crowned sparrows. Condor, 98, 567-580.

Clergeau, P. (1993). Fonctions des dortoirs nocturnes d'oiseaux: Hypothèses historiques et apport du modèle étourneau. L'Oiseau R. F. O., 63, 87-105.

Clobert, J., \& Berthet, P. (1983). Les jeunes habitent petit ou impact de la réduction du volume intérieur du nichoir sur le comportement d'une population nicheuse d'étourneaux sansonnets. Annales Société Royale Zoologique Belge, 113, 183-192.

Conrads, K. (1966). Der Egge-Dialekt des Buchfinken (Frigilla coelebs). Ein Beitrag zur geographischen Gesangsvariation. Die Vogelwelt, 87, 176-182.

Coupland, N. (2001). Language, situation, and the relational self: Theorizing dialect-style in sociolinguistics. In P. Eckert \& J. R. Rickford (Eds.), Style and sociolinguistic variation (pp. 185-210). New York: Cambridge University Press.

Cousillas, H., George, I., Henry, L., Richard, J. P., \& Hausberger, M. (2008). Linking social and vocal brains: Could social segregation prevent a proper development of a central auditory area in a female songbird? Plos One, 3(5), e2194. doi:10.1371/journal.Pone.0002194.

Cousillas, H., Mathelier, M., Richard, J. P., Henry, L., \& Hausberger, M. (2006). Social experience: A major factor in the development of a central auditory area. Naturwissenchaften, 93, 588-596.

Cousillas, H., Richard, J. P., Mathelier, M., Henry, L., George, I., \& Hausberger, M. (2004). Experience-dependent neuronal specialization and functional organization in the central auditory area of a songbird. European Journal of Neuroscience, 19, 3343-3352.

Crockford, C., Herbinger, I., Vigilant, L., \& Boesh, C. (2004). Wild chimpanzees produce group-specific calls: A case for vocal learning? Ethology, 110, 221-243.

Davidson, S. M., \& Wilkinson, G. S. (2002). Geographic and individual variation in vocalizations by male Saccopteryx bilineata (Chiroptera: Emballonuridae). Journal of Mammalogy, 83, 526-535.

Darwin, C. (1871). The descent of man, and selection in relation to sex. London: John Murray.

De la Torre, S., \& Snowdon, C. T. (2009). Dialects in pygmy marmosets? Population variation in call structure. American Journal of Primatology, 71, 333-342. 
Deecke, V., Ford, J. K. B., \& Spong, P. (2000). Dialect change in resident killer whales (Orcinus orca): Implications for vocal learning and cultural transmission. Animal Behaviour, 60, 619-638.

Deleporte, P. (2002). Phylogenetics and the aptationist program. Commentary / Andrews et al.: Adaptationism how to carry out an exaptationist program. Behavioural and Brain Sciences, 25, 514-515.

Delvaux, V., \& Soquet, A. (2007). The influence of ambient speech on adult speech productions through unintentional imitation. Phonetica, 64, 145-173.

Doupe, A., \& Kuhl, P. K. (1999). Birdsong and speech: Common themes and mechanisms. Annual Review of Neuroscience, 22, 567-631.

Dufty, A. M. Jr., \& Hanson, A. (1999). Vocal and behavioural responses of brown-headed cowbirds to flight whistles from different dialects. Condor, 101, 484-492.

Dyer, J. (2002). "We all speak the same round here": Dialect leveling in a Scottish-English community. Journal of Sociolinguistics, 6, 99-116.

Eaton, R. L. (1974). A beluga whale imitates human speech. Carnivore, 2, 22-23.

Eckert, P. (2000). Linguistic variation as social practice. Oxford: Blackwell.

Eriksen, N., Millar, L. A., Tougaard, J., \& Helweg, D. A. (2005). Cultural change in the songs of humpback whales (Megaptera novaeangliae) from Tonga. Behaviour, 142, 305-328.

Esser, K. H., \& Schubert, J. (1998). Vocal dialects in the lesser spear-nosed bat Phyllostomus discolor. Naturwissenschaften, 85, 347-349.

Falls, J. B. (1982). Individual recognition by sounds in birds. In D. E. Kroodsma \& E. H. Miller (Eds.), Acoustic communication in birds, Vol. 2 (pp. 237-278). New York: Academic Press.

Fasold, R. W. (1985). Bird-song dialects and human-language dialects: A common basis? Behavioral and Brain Sciences, 8,104-105.

Feare, C. (1984). The starling. Oxford University Press, New York.

Feekes, F. (1982). Song mimesis within colonies of Cacicus c. cela (Leteridae, Aves). A colonial password? Zeitschrift für Tierpsychologi, 52, 119-152.

Ficken, M. S., \& Ficken, C. M. (1984). A complex call of the black-capped chickadee (Parus atricapillus). I. Microgeographic variation. Auk, 101, 349-360.

Fitch, W. T., \& Hauser, M. D. (1995). Vocal production in nonhuman primates: Acoustics, physiology and functional constraints on honest advertisement. American Journal of Primatology, 37, 191-219.

Flux, J. E. C., \& Flux, M. M. (1981). Population dynamics and age-structure of starlings in New-Zeland. New Zeland Journal of Ecology, 4, 65-72.

Ford, J. K. B. (1989). Acoustic behaviour of resident killer whales (Orcinus orca) in British Columbia. Canadian Journal of Zoology, 67, 727-745.

Ford, J. K. B. (1991). Vocal traditions among resident killer whales (Orcinus orca) in coastal waters of British Columbia. Canadian Journal of Zoology, 69, 1454-1483.

Foulkes, P., \& Docherty, G. (2006). The social life of phonetics and phonology. Journal of Phonetics, 34, 409-438.

Foulkes, P., Docherty, G., \& Watt, D. J. L. (2005). Phonological variation in child directed speech. Language, 81, 177-206.

Freeberg, T. M., King, A. P., \& West, M. J. (2001). Cultural transmission of vocal traditions in cowbirds (Molothrus ater) influences courtship patterns and mate preferences. Journal of Comparative Psychology, 115, 201211.

Freeberg, T. M., \& White, D. J. (2006). Social traditions and the maintenance and loss of geographic variation in mating pattern of brown headed cowbirds. International Journal of Comparative Psychology, 19, 206-222.

Goodale, E., \& Podos, J. (2010). Persistence of song types in Darwin's finches, Geospiza fortis, over four decades. Biology Letters, 6, 589-592.

Gould, J. L. (1982). Why do honey bees have dialects? Behavioural Ecology and Sociobiology, 10, 53-56.

Grant, B. R. (1984). The significance of song variation in a population of Darwin's finches. Behaviour, 89, 90-116.

Green, S. M. (1975). Dialects in Japanese monkeys: Vocal learning and cultural transmission of local-specific vocal behavior? Zeitschrift für Tierpsychologie, 38, 304-314.

Hafen, T., Neveu, H., Rumpler, Y., Wilden, I., \& Zimmermann, E. (1998). Acoustically dimorphic advertisement calls separate morphologically and genetically homogenous populations of the grey mouse lemur (Microcebus murinus). Folia Primatologica, 69, 342-356.

Hammerschmidt, K., \& Fischer, J. (2008). Constraints in primate vocal production. In K. Oller \& U. Griebel (Eds.), Evolution of communicative flexibility: Complexity, creativity and adaptability in human and animal communication (pp. 93-119).Cambridge, MA: MIT Press. 
Handford, P., \& Nottebohm, F. (1976). Allozymic and morphological variation in population sample of rufouscollared sparrow, Zonotrichia capensis, in relation to vocal dialect. Evolution, 30, 802-817.

Hansen, P. (1985). Geographic variations in the yellow hammer (Emberizia citronella). Bioacoustics, 9, 281-295.

Hausberger, M. (1997). Social influences on song acquisition and sharing in the European starling (Sturnus vulgaris). In C. T. Snowdon \& M. Hausberger (Eds.), Social influences on vocal development (pp. 128156). Cambridge, UK: Cambridge University Press.

Hausberger, M., Bigot, E., \& Clergeau, P. (2008). Dialect use in large assemblies: A study in European starling roosts. Journal of Avian Biology, 39, 672-682.

Hausberger, M., Black, J. M., \& Richard, J. P. (1991). Bill opening and sound spectrum in barnacle goose loud calls: Individuals with 'wide mouths' have higher pitched voices. Animal Behaviour, 42, 319-322.

Hausberger, M., Cousillas, H., George, I., \& Henry, L. (2002). Les bases neurologiques du chant des oiseaux. Dossier Pour La Science, 34, 68-74.

Hausberger, M., \& Guyomarc'h, J. C. (1981). Contribution à l'étude des vocalisations territoriales sifflées chez l'étourneau sansonnet Sturnus vulgaris en Bretagne. Biology of Behaviour, 6, 79-98.

Hausberger, M., Henry, L., Testé, B., \& Barbu, S. (2008). Contextual sensitivity and birdsong: A basis for social life. In K. Oller \& U. Griebel (Eds.), Evolution of communicative flexibility: Complexity, creativity and adaptability in human and animal communication (pp. 121-138).Cambridge, MA: MIT Press.

Hausberger, M., Richard-Yris, M. A., Henry, L., Lepage, L., \& Schmidt, I. (1995). Song sharing reflects the social organization in a captive group of European starlings (Sturnus vulgaris). Journal of Comparative Psychology, 109, 222-241.

Hauser, M. D., Chomsky, N., \& Fitch, T. W. (2002). The faculty of language: What is it, who has it, and how did it evolve? Science, 298, 1569-1579.

Henry, L., \& Hausberger, M. (2001). Differences in the social context of song production in captive male and female European starlings. Comptes Rendus Académie des Sciences, 324, 1167-1174.

Hinde, R. A. (1976). Interactions, relationships and social structure. Man, 11, 1-17.

Hiss, A. (1983). Hoover. The New Yorker, 3, 25-27.

Hopkins, W. D., Taglialatela, J., \& Leavens, D. (2007). Chimpanzees differentially produce novel vocalizations to capture the attention of a human. Animal Behaviour, 73, 81-286.

Hunter, M. L. Jr., \& Krebs, J. R. (1979). Geographical variation in the song of the great tit,(Parus major) in relation to ecological factors. Journal of Animal Ecology, 48, 759-785.

Janik. V. M., \& Slater, P. B. J. (1997). Vocal learning in mammals. Advances in the Study of Behaviour, 26, 59-99.

Jenkins, P. F. (1978). Cultural transmission of song patterns and dialect development in a free-living bird population. Animal Behaviour, 26, 50-78.

Kershenbaum, A., Ilany A., Blaustein, L., \& Geffen, E. (2012). Syntactic structure and geographical dialect in the song of male rock hyraxes. Proceedings Royal Society of London B, 279, 2974-2981.

Kerswill, P., \& Williams, A. (2000). Creating a new town koine: Children and language change in Milton Keynes. Language in society, 29, 65-115.

Koda, H., Lemasson, A., Oyakawa, O., Rizaldi, Pamungkas, J., \& Masataka, N. (2013). Possible role of motherdaughter vocal interactions on the development of species-specific song in gibbons. PLoS ONE, 8(8), e71432.

Kremers, D., Lemasson. A., Almunia, J., \& Wanker, R. (2012). Vocal sharing and individual acoustic distinctiveness within a group of captive orcas. Journal of Comparative Psychology, 126, 433-445.

Kreutzer, M. (1974). Réponses comportementales des mâles troglodytes (Passeriformes) à des chants spécifiques de dialectes différents. Revue de Comportement Animal, 8, 287-295.

Labov, W. (1972). Sociolinguistic patterns. Oxford: Blackwell.

Labov, W. (2001). Principles of linguistic change, Vol. 2: Social factors. Oxford: Blackwell

Labov, W. (2002). Driving forces in linguistic change. Paper presented at the International Conference on Korean Linguistics, Seoul National University, Seoul, Korea. Retrieved from http://www.ling.upenn.edu/ wlabov/Papers/DFLC.htm.

Lachlan, R. F. (2008). The evolution of flexibility of song. In K. Oller \& U. Griebel (Eds.), Evolution of communicative flexibility: Complexity, creativity and adaptability in human and animal communication (pp. 305-325).Cambridge, MA: MIT Press.

Lachlan, R. F., \& Slater, P. J. B. (2003). Song learning in chaffinches: How accurate, and from where? Animal Behaviour, 65, 957-969. 
Leader, N., Geffen, E., Mokady, O., \& Yom-Tov, Y. (2008). Song dialects do not restrict gene flow in an urban population of the orange-tufted sunbird, Nectarinia osea. Behavioural Ecology and Sociobiology, 62, 1299-1305.

Leader, N., Wright, J., \& Yom-Tov, Y. (2002). Dialect discrimination by male orange-tufted sunbirds (Nectarinia osea): Reactions to own vs neighbor dialects. Ethology, 108, 367-376.

Leader, N., Wright, J., \& Yom-Tov, Y. (2005). Acoustic properties of two urban song dialects in the orange-tufted sunbird (Nectarinia osea). Auk, 12, 231-245.

Le Bœuf, B. J., \& Peterson, R. S. (1969). Dialects in elephant seals. Science, 166, 1654-1656.

Lee, H. P., \& Gourley, L. (1988). Classification of Chinese cancer patients by dialectal group: Is it still valid? Annals Academy of Medecine, 17, 431-433.

Lemasson, A. (2011). What can forest guenons «tell » us about the origin of language? In J. L. Schwartz, A. Vilain, A. Christian, \& J. Vauclair (Eds.), Primate communication and human language: Vocalisation, imitation, and deixis in humans and non-humans (pp. 39-70). Amsterdam: John Benjamins Publishing Company.

Lemasson, A., Boutin, A., Boivin, S., Blois-Heulin, C., \& Hausberger, M. (2009). Horse (Equus caballus) whinnies, a source of social information. Animal Cognition, 12, 693-704.

Lemasson, A., \& Hausberger, M. (2004). Patterns of vocal sharing and social dynamics in a captive group of Campbell's monkeys. Journal of Comparative Psychology, 118, 347-359.

Lemasson. A., \& Hausberger, M. (2011). Acoustic variability and social significance of calls in female Campbell's monkeys (Cercopithecus campbelli campbelli). Journal of the Acoustical Society of America, 129, 33413352.

Lemasson, A., Mikus, M.-A., Blois-Heulin, C., \& Lodé, T. (2014). Vocal repertoire, acoustic individual distinctiveness and social networks in a group of captive Asian small-clawed otters (Aonyx cinereus). Journal of Mammalogy, in press. .

Lemasson. A., Ouattara, K., Petit, E., \& Zuberbühler, K. (2011). Social learning of vocal structure in a nonhuman primate? BMC Evolutionary Biology, 11, 362.

Lemasson, A., Richard, J. P., \& Hausberger, M. (2004). A new methodological approach to context analysis of call production. Bioacoustics, 14, 111-125.

Lemasson. A., Remeuf, K., Rossard, A., \& Zimmermann, E. (2012). Cross-taxa similarities in affect-induced changes of vocal behavior and voice in arboreal monkeys. PloS ONE, 7(9), e45106. doi:10.1371/journal.pone.0045106

Lemasson, A., Zuberbühler, K., \& Hausberger, M. (2005). Socially meaningful vocal plasticity in Campbell's monkeys. Journal of Comparative Psychology, 119, 220-229.

Lehtonen, L. (1983). The changing song patterns of the great tits Parus major. Ornis Fennica, 60, 16-21.

Lemon, R. E. (1966). Geographic variation in the song of cardinals. Canadian Journal of Zoology, 44, 413-428.

Lindauer, M. (1977). Recent advances in the orientation and learning of honeybees. Proceedings of the XV international Congress on Entomology, 450-460.

Lougheed, S. C., Handford, P., \& Baker, A. J. (1993). Mitochondrial DNA hyperdiversity and vocal dialects in a subspecies transition of the rufous-collared sparrow. Condor, 95, 889-895.

Maeda, T., \& Masataka, N. (1987). Locale-specific vocal behaviour of the tamarin (Saguinus l. labiatus). Ethology, 75, 25-30.

Marler, P. (1952). Variation in the song of the chaffinch, Fringilla coelebs. Ibis, 94, 458-472.

Marler, P. (1970a). Bird song and human speech. Could there be parallels? American Scientist, 58, 669-674.

Marler, P. (1970b). A comparative approach to vocal learning: Song development in white-crowned sparrows. Journal of Comparative Physiology and Psychology (Monography), 71, 1-25.

Marler, P. (1977). The structure of animal communication sound. In T. H. Bullock (Ed), Recognition of complex acoustic signal (pp. 17-35). Berlin: Dahlem Konference.

Marler, P., \& Tamura, M. (1962). Song "dialects" in three populations of white-crowned sparrows. Condor, 64, $368-377$.

Marler, P., \& Tamura, M. (1964). Culturally transmitted patterns of vocal behavior in sparrows. Science, 146, 14831486.

Martins, E. P. (1996). Phylogenies and the comparative method in animal behaviour. Oxford: Oxford University Press.

Masataka, N. (2003). The onset of language. Cambridge University Press, UK.

Mc Cowan, B., \& Reiss, D. (1997). Vocal leaning in captive dolphins: A comparison with humans and nonhuman animals. In C. T. Snowdon \& M. Hausberger (Eds.), Social influences on vocal development (pp. 178-207). Cambridge: Cambridge University Press, UK. 
Merkel. F. W. (1980). Sozialverhalten von individuelle markierten Staren (Sturnus vulgaris) in einer kleinen Nistkastenkolonie (3. Mitteilung). Luscinia, 44, 133-158.

Milroy, L. (2002). Introduction: Mobility, contact and language change - Working with contemporary speech communities. Journal of Sociolinguistics, 6, 3-15.

Motis, A. (1994). Territorialitat interspecifica de (Sturnus vulgaris L.) i (Sturnus unicolor), dues aloespècies en contacte secundari: Hàbitat de cria, conducta agonistica i cants territorials. (Unpublished doctoral dissertation). University of Barcelona, Spain.

Moulton, W. G. (1985). Bird-song dialects and human-language dialects. Behavioral and Brain Sciences, 8, 110111.

Mundinger, P. C. (1982). Microgeographical and macrogeographical variation in the acquired vocalization of birds. In D. E. Kroodsma \& E. H. Miller (Eds.), Acoustic communication in birds (pp. 147-208). New York: Academic Press.

Nagoshi, C. T., Johnson, R. C., \& Danko, G. P. (1990). Assortative mating for cultural identification as indicated by language use. Behavior Genetics, 20, 23-31.

Nardy, A., Chevrot, J. P., \& Barbu, S. (2013). The acquisition of sociolinguistic variation: Looking back and thinking ahead. Linguistics, 51, 2, 255-284.

Nethersole-Thompson, D. (1966). The snow bunting. Edinburgh: Olivier \& Boyd.

Nevo, E., Heth, G., Beiles, A., \& Frankenberg, E. (1987). Geographical dialects in blind mole rats: Role of vocal communication in active speciation. Proceedings of National Academy of Science, 84, 3312-3315.

Nicholls, J. A. (2008). Site specificity in advertisement calls and responses to playbacks of local and foreign variants in satin bowerbirds, Ptilonorhynchus violaceus. Behaviour, Ecology and Sociobiology, 62, 831-841.

Noad, M. J., Cato, D. H., Bryden, M. M., Jenner, M. N., Curt, K., \& Jenner, S. (2000). Cultural revolution in whale songs. Nature, 408, 537.

Nottebohm, F. (1969). The song of the Chingolo (Zonotrichia capensis) in Argentina: Description and evaluation of a system of dialects. Condor, 71, 299-135.

Nottebohm, F. (1989). From birdsong to neurogenesis. Scientific American, 260, 74-79.

Nowicki. S. (1989). Vocal plasticity in captive black-capped chickadees: The acoustic basis and rate of call convergence. Animal Behaviour, 37, 64-73.

Ouattara, K., Zuberbühler, K., N'goran, E. K., Gombert, J. E., \& Lemasson, A. (2009). The alarm call system of female Campbell's monkeys. Animal Behaviour, 78, 35-44.

Owren, M. J., Dieter, J. A., Seyfarth, R. M., \& Cheney, D. L. (1992). Evidence of limited modification in the vocalizations of cross-fostered rhesus Macaca mulatta and Japanese $M$. fuscata macaques. In T. Nishida, W.C.McGrew, P. Marler, M. Pickford, \& F. de Waal (Eds.), Topics in primatology, Vol. 1: Human origins (pp. 257-270). Tokyo: University of Tokyo Press.

Pardo, J. S. (2006). On phonetic convergence during conversational interaction. Journal of the Acoustical Society of America, 119, 2382-2393.

Patterson, J. L. (1992). The development of sociolinguistic phonological variation patterns for (ING) in young children. (Unpublished doctoral dissertation). Albuquerque, NM: University of New Mexico.

Pavlova, D., Pinxten, R., Darras, V., \& Eens, M. (2007). Effects of nestboxes and males on female song activity in the European starling: An experimental study. Behaviour, 144, 1255-1271

Payne, R. B. (1981). Population structure and social behavior: Models for testing the ecological significance of song dialects in birds. In R. D. Alexander \& D. W. Tinkle (Eds.), Natural selection and social behaviour, research and new theories (pp. 108-120). New York: Chiron Press.

Payne, R. B. (1983). The social context of song mimicry: Song matching dialects in indigo bunting. Animal Behaviour, 31, 788-805.

Payne, R. B., \& Payne, L. L. (1997). Field observations, experimental design, and the time and place of learning bird song. In C. T. Snowdon \& M. Hausberger (Eds.), Social influences on vocal development (pp. 57-84). Cambridge, UK: Cambridge University Press.

Payne, R. B., Payne, L. L., \& Rowley, I. (1988). Kin and social relationships in splendid fairy-wrens: Recognition by song in a cooperative birds. Animal Behaviour, 35, 1351-1351.

Payne, R. B., \& Westneat, D. F. (1988). A genetic and behavioural analysis of mate choice and song neighborhoods in indigo buntings. Evolution, 42, 935-947. 
Pepperberg, I. M. (1997). Social influences on the acquisition of human-based codes in parrots and non-human primates In C. T. Snowdon \& M. Hausberger (Eds.), Social influences on vocal development (pp. 157177). Cambridge, UK: Cambridge University Press.

Petrinovitch, L. (1988). The role of social factors in white-crowned sparrow song development. In T. R. Zentall \& B. G. Jr. Galef (Eds.), Social learning: Psychological and biological perspectives (pp. 255-278). Hillsdale, NJ: Erlbaum.

Petrinovitch, L., \& Baptista, L. F. (1984). Song dialects, mate selection and breeding success in white-crowned sparrows. Animal Behaviour, 32, 1078-1088.

Petrinovitch, L., \& Patterson, T. (1981). The response of white crowned sparrows to songs of different dialects and subspecies. Zeitschrift für Tierpsychologie, 57, 1-44.

Petrinovitch, L., Patterson, T., \& Baptista, L. F. (1981). Song dialect as barriers to dispersal: A re-evaluation. Evolution, 35, 80-188.

Petyt, K. M. (1980). The study of dialect: An introduction to dialectology. London: A. Deutsch

Pliny the Elder. (1848-1850). Histoire naturelle, livre X, XLIII. Émile Littré. Paris: Dubochet.

Podos. J. (2007). Discrimination of geographical song variants by Darwin's finches. Animal Behaviour, 73, 833844.

Podos, J. \& Warren, P. S. (2007). The evolution of geographic variation in birdsong. Advances in the Study of Behavior, 37, 403-458.

Poirier, C., Henry, L., Mathelier, M., Lumineau, S., Cousillas, H., \& Hausberger, M. (2004). Direct social contacts override auditory information in the song-learning process in starlings (Sturnus vulgaris). Journal of Comparative Psychology, 118, 179-193.

Poole, J. H., Tyack, P. L., Stoeger-Horwath, A. S., \& Watwood, S. (2005). Two animals coin unexpected sounds as a surprising form of social communication. Nature, 434, 455-456.

Poulsen, H. (1951). Inheritance and learning in the song of the chaffinch, Fringilla coelebs. Behaviour, 3, 216-228.

Promptoff, A. (1930). Die geographische Variabilität des Buchfinkenschlags (Fringilla coelebs L.) in Zusammenhaug mit etlichen allgemeinen Fragen der Saisonvögelzuge. Biologisches Zentralblatt, 50, 478503.

Randall, J. A. (1994). Convergences and divergences in communication and social organization of desert rodents. Australian Journal of Zoology, 42, 404-433.

Randall, J. A. (1995). Modification of footdrumming signatures: Changing territories and gaining new neighbours. Animal Behaviour, 49, 1227-1237.

Reby, D., \& McComb, K. (2003). Anatomical constraints generate honesty: Acoustic cues to age and weight in the roars of red deer stags. Animal Behaviour, 65, 519-530.

Rendell, L., \& Whitehead, H. (2001). Culture in whales and dolphins. Behavioral and Brain Sciences, 24, 309-324.

Rendell, L. E., Matthews, J. N., Gordon, J. C. D., \& MacDonald, D. W. (1999). Quantitative analysis of tonal calls from five odontocete species, examining interspecific and intraspecific variation. Journal of Zoology, 249, 403-410.

Ridgway, S., Carder, D., Jeffries, M., \& Todd, M. (2012). Spontaneous human speech mimicry by a cetacean. Current Biology, 22, 2144-2148.

Riesch, R., Ford, J. K. B., \& Thomsen, F. (2006). Stability and group specificity of stereotyped whistles in resident killer whales, Orcinus orca, off British Columbia. Animal Behaviour, 71, 79-91

Roberts, J. (2002). Child language variation. In F. K. Chambers, P. Trudgill \& N. Schilling-Estes (Eds.), The handbook of language variation and change (pp. 333-348). Oxford: Blackwell.

Rossi-Santos, M. R., \& Podos, J. (2006). Latitudinal variation in whistle structure of the estuarine dolphin Sotalia guianensis. Behaviour, 143, 347-364.

Schilling-Estes, N. (2002). On the nature of isolated and post-isolated dialects: Innovation, variation and differentiation. Journal of Sociolinguistics, 6, 64-85.

Schlenker, P., Chemla, E., Arnold, K., Lemasson, A., Ouattara, K., Keenan, S., ... Zuberbühler, K. (2014). Monkey semantics: Two 'dialects' of Campbell's monkey alarm calls. Linguistic and Philosophy, 37, 439-501. doi: $10.1007 / \mathrm{s} 10988-014-9155-7$

Schustermann, R. J. (2008). Vocal learning in mammals with special emphasis on pinnipeds. In K. Oller \& U. Griebel (Eds.), Evolution of communicative flexibility: Complexity, creativity and adaptability in human and animal communication (pp. 41-70).Cambridge, MA: MIT Press. 
Shepard, C. A., Giles, H., \& Le Poire, B. A. (2001). Communication accommodation theory. In P. W. Robinson \& H. Giles (Eds.), The new handbook of language and social psychology (pp 33-56). Chichester, UK: John Wiley \& Sons.

Slater, P. J. B., Ince, S. A., \& Colgan, P. W. W. (1980). Chaffinch song types: Their frequencies in the population and distribution between the repertoires of different individuals. Behaviour, 75, 207-218.

Slocombe, K. E., \& Zuberbühler, K. (2007). Chimpanzees modify recruitment screams as a function of audience composition. Proceedings of the National Academy of Sciences, 104, 17228-17233.

Smith, J., Durham, M., \& Fortune, L. (2007). 'Mam, my trousers is fa'in doon!': Community, caregiver and child in the acquisition of variation in a Scottish dialect. Language Variation and Change, 19, 63-99.

Smith, J., Durham, M., \& Fortune, L. (2009). Universal and dialect-specific pathways of acquisition: Caregivers, children, and t/d deletion. Language Variation and Change, 21, 69-95.

Smolker, R., \& Pepper, J. W. (1999). Whistles convergence among allied bottlenose dolphins (Delphinidae, Tursiops sp.). Ethology, 105, 595-617.

Snowdon, C. T., Elowson, M. A., \& Roush, R. S. (1997). Social influences on vocal development in New World primates. In C. T. Snowdon \& M. Hausberger (Eds.), Social influences on vocal development (pp. 234248). Cambridge UK: Cambridge University Press.

Snowdon, C. T., \& Hausberger, M. (1997). Social influences on vocal development. Cambridge, UK: Cambridge University Press.

Spitler-Nabors, K. J., \& Baker, M. C. (1983). Reproductive behavior by a female songbird: differential stimulation by natal and alien song dialects. Condor, 85, 491-494.

Stanfort, J. N. (2010). The role of marriage in linguistic contact and variation: Two Hmong dialects in Texas. Journal of Sociolinguistics, 14, 89-115.

Strange, W., \& Jenkins. J. J. (1978). Role of linguistic experience in the perception of speech. In R. D. Walk \& H. L. Pick (Eds.), Perception and experience (pp. 125-169). New York: Academic.

Suthers, R. A., \& Margoliash, D. (2002). Motor control of birdsong. Current Opinion in Neurobiology, 12, 684-690.

Tanaka, T., Hideki, S., \& Masataka, N. (2006). Cross-sectional and longitudinal studies of the development of group differences in acoustic features of coo calls in two groups of Japanese macaques. Ethology, 112, 7-21.

Thielcke, G. (1965). Gesangsgeographische variation des gartenbaumläufers (Certhia brachydactyla) im hinblick auf das artbildungsproblem. Zeitschrift für Tierpsychologie, 22, 542-566.

Thielcke, G. (1969). Geographic variation in bird vocalization. In R. A. Hinde (Ed.), Bird vocalizations (pp.311339). Cambridge, UK University Press.

Thomsen, F., Franck, D., \& Ford, J. K. B. (2002). On the communicative significance of whistles in wild killer whales (Orcinus orca). Naturwissenschaften, 89, 404-407.

Thorpe, W. H. (1954). The process of song-learning in the Chaffinch as studied by means of the sound spectrograph. Nature, 173, 465-469.

Thorpe, W. H. (1958). The learning of song patterns by birds, with special reference to the songs of the chaffinch Fringilla coelebs. Ibis, 100, 535-570.

Thorpe, W. H. (1961). Bird song. Cambridge University Press, UK.

Thorpe, W. H., \& North, M. E. W. (1965). Origin and significance of the power of vocal imitation: With special reference to the antiphonal singing of birds. Nature, 208, 219-222.

Tomback, D. F., Thompson, D. B., \& Baker, M. C. (1983). Dialect discrimination by white crowned sparrows: Reactions to near and distant dialects. Auk, 100, 452-460.

Trainer, J. M. (1989). Cultural evolution in song dialects of yellow-rumped caciques in Panama. Ethology, 80, 190204.

Trudgill, P. (1986). Dialects in contact. Oxford: Blackwell.

Tyack, P. L. (1986). Population biology, social behaviour, and communication in whales and dolphins. Trends in Ecology and Evolution, 1, 144-150.

Tyack, P. L. (2000). Dolphins whistle a signature tune. Science, 289, 1310-1311.

Tyack, P. L., \& Miller, E. H. (2002). Vocal anatomy, acoustic communication and echolocation. In A. R. Hoelzel (Ed.), Marine mammal biology: An evolutionary approach (pp. 142-184). Oxford: Blackwell Science Ltd.

Tyack, P. L., \& Sayigh, L. S. (1997). Vocal leaning in cetaceans. In C. T. Snowdon \& M. Hausberger (Eds.), Social influences on vocal development (pp. 142-184). Cambridge, UK: Cambridge University Press,.

Volodin, I. A.,Volodina, E. V., Lapshina, E. N., Efremova, K. O. \& Soldatova, N. V. (2013). Vocal group signatures in the goitred gazelle Gazella subgutturosa, Animal Cognition, doi: 10.1007/s10071-013-0666-3 
Ward, R. (1966). Regional variation in the song of the Carolina Chickadee. Living Bird, 5, 127-150.

West, M. J., \& King, A. P. (1990). Mozart's starling. American Scientist, 7, 106-114.

Wich, S. A., Krützen, M., Lameira, A. R., Nater, A., Arora, N., Bastian, M. L., ...van Schaik, C. P. (2012). Call cultures in orang-utans? PLoS one, 7, e36180.

Wiens, J. A. (1982). Song pattern variation in the sage sparrow (Amphispiza belli): Dialects or epiphenomena? Auk, 99, 208-229.

Wiley, R. H., \& Richards, D. G. (1983). Adaptation for acoustic communication in birds: Sound transmission and signal detection. In D. E. Kroodsma \& E. H. Miller (Eds.), Acoustic communication in birds (pp. 131-181). New York: Academic Press.

Winter, P., Handley, P., Ploog, D., \& Schott, D. (1973). Ontogeny of squirrel monkey calls under natural conditions and under acoustic isolation. Behaviour, 47, 230-239.

Wolfram, W. (1998). Dialect in society. In F. Coulmas (Ed.), The handbook of sociolinguistics (pp. 107-126). Oxford: Blackwell.

Wright, T. F. (1996). Regional dialects in the contact call of a parrot. Proceedings of the Royal Society of London B, 263, 867-872.

Wright, T. F., \& Dorin, M. (2001). Pair duets in the yellow-napped amazon (Amazona auropalliata): Responses to playbacks of different dialects. Ethology, 107, 111-124.

Wright, T. F., Rodriguez, A., \& Fleischer, R. C. (2005). Vocal dialects, sex-biased dispersal and microsatellite population structure in the parrot Amazona auropalliata. Molecular Ecology, 14, 1197-1205.

Wycherley, J., Doran, S., \& Beebee, T. J. C. (2002). Frog calls echo microsatellite phylogeography in the European pool frog (Rana lessonae). Journal of Zoology, 258, 479-484.

Yurk, H., Barrett-Lennard, L. G., Ford, J. K. B., \& Matkin, C. O. (2002). Cultural transmission within maternal lineages: Vocal clans in resident killer whales in southern Alaska. Animal Behaviour, 63, 1103-1119.

Zuberbühler, K., Ouattara, K., Bitty, A., Lemasson, A., \& Noë, R. (2009). The primate roots of human language: Primate vocal behaviour and cognition in the wild. In F. d'Errico \& J. M. Hombert (Eds.), Becoming eloquent: Advances in the emergence of language, human cognition, and modern culture (pp. 235-264). Amsterdam: John Benjamins Publishing Company. 